\title{
Socio-economic Changes in Poland in the Period 2004-2013
}

\author{
Margarita Illeva, Bydgoszcz, and Iliya ILIEv, Sofia [Sofija]*
}

with 8 figures and 3 tables in the text

\section{Content}

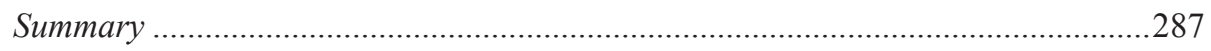

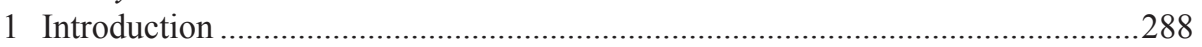

2 Socio-economic changes at the national level........................................................28

3 Socio-economic changes by NUTS-2 regions.....................................................293

4 Socio-economic changes at the local level: Case study of Gołdap

Municipality and the City of Bydgoszcz.........................................................300

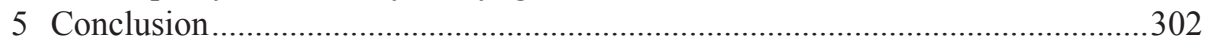

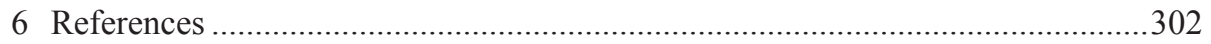

\section{Summary}

This paper focuses on socio-economic changes in Poland - the biggest country of EU Eastern enlargement - over the past 10 years, from a geographical point of view and as perceived by foreigners. The leading consideration in the choice of topic of this investigation was that Poland, compared with the other Central and Eastern European members of $E U$, has maintained a more stable growth of economic development in the period of transition and EU membership. This research refers to territorial differences in socio-economic changes in Poland at several territorial levels - national, regional, local. Comparisons are also made with other EU countries.

\footnotetext{
* Margarita Ilieva, Professor, DSc., Institute of Geography, Kazimierz Wielki University, 85-428 Bydgoszcz, 15 Mińska str., Poland; email: ilieva@abv.bg; Iliya ILIEv, Assoc. Prof. PhD., Sofia University St. Kliment Ochridski; email: ilipeti@abv.bg
} 


\section{Introduction}

The current complicated and deep political and socio-economic processes, which started towards the end of the 1980s in Central and Eastern European states, are an interesting issue for researchers. The analysis, interpretation and evaluation of these highly varied processes have been investigated from different points of view (theoretical, on the basis of concrete investigations, etc.) and on different spatial scales (Central and Eastern Europe, some countries from this region, selected countries or regions in these countries) in the last decades (Gorzelak 1995; DOMAŃSKI 1997; FASSMANN 1997; Smith \& Pickles 1998; Czyż 1998; Parysek 1998; Förster 2000; Stadelbauer 2000; Horvath 2002; Ilieva 2002, 2012, 2013; Eberhardt \& Ilieva 2004; Conford et al. 2006; Michalski 2006; Rydz 2006; KoŁodKo 2008; Fabrizio, Leigh \& Mody 2009; Kitowski 2010; Kollmorgen 2010; Szanyi 2013; etc.). The processes of change coincided with the processes of political and economic integration of these countries into the European Union (EU). Petrakos (2002) considers the aforesaid processes to be two major events, which stand out in the last decade of the $20^{\text {th }}$ century in Europe.

Poland is the biggest country among eleven members states of the EU from Central and Eastern Europe. It constitutes 7.4\% of the EU-28 territory and $7.5 \%$ of the overall population, generating 4.9\% of the Gross Domestic Product (GDP) in 2012 (estimate). The achieved level of socio-economic development of the country is due to transformation processes over the last two decades and the impact of many different economic, political, demographic and other factors. Among the factors constituting the sources of Poland's development the National Development Strategy (2006) includes "population potential, high entrepreneurship, investment attractiveness, natural environment, structure of the spatial development of the country and also the Polish culture" (p. 12), "relatively high qualification of employees, political and economic stability, an unlimited access to the Union's internal market and a small distance to the largest Union market" (p. 13). Additionally, European funds are "a significant external factor affecting the stability of the economy” (MASIK \& RZYSKI 2014, p. 132).

An analysis of publications shows that the researchers have used both single indicators and integral indicators. Gross Domestic Product is one of the most commonly applied parameters both in individual countries and across regions (CZYŻ 1998; Parysek 1998; Mync \& Komornicki 2000; Hrubi 2002; Ilieva 2002, 2012, 2013a, 2013b; Enyedi 2005; Tarkowski 2008; Horvath 2009; Bracalente \& Perugini 2010; IANOŞ et al. 2013; etc.). A number of other indicators are also used to investigate socio-economic changes on the national, regional or local levels - indicators describing population, development of the business environment and economy, the labour market, competition, changes in social relations, etc. Recent European and national strategic documents in compliance with the goals of achieving smart, sustainable and cohesive growth have determined GDP per capita, the employment rate, the R\&D spending as percentage of GDP, the power generated from renewable energy sources, the share 
of university graduates, etc., to be the most important indicators. ("EUROPE 2020" Strategy and national documents, related to it - Ministerstwo Regionalnego Rozwoju 2012; Koncepcija Przestrzennego Zagospodarowania 2012, etc.)

This investigation applies various indicators to present ongoing changes at different levels - GDP, coefficient of entrepreneurship, EU co-financing, Foreign Direct Investment (FDI) flows, employment, etc. For a better comparison some of the indicators are calculated on a per capita basis. The research is based on the current statistical data for the period 2000-2013, obtained from Eurostat, the Central Statistical Office of PolAnd, national strategic documents, documents and publications of the EUROPEAN Commission, publications of various authors and organisations, as well as the authors' publications.

\section{Socio-economic changes at the national level}

Poland has maintained more stable growth of economic development in the period of transition and EU membership, compared to other Central and Eastern European member states. The analysis of key indicators shows a continuation of a number of positive trends and structural changes, which began during 1990s in the Polish economy, throughout the period 2004-2011 too (Fig. 1). Generated GDP in the country increased in the period 1990-2012 more than 2.2 times.

Figure 1: Dynamics of Polish national economy 2004-2013 (previous year=100)

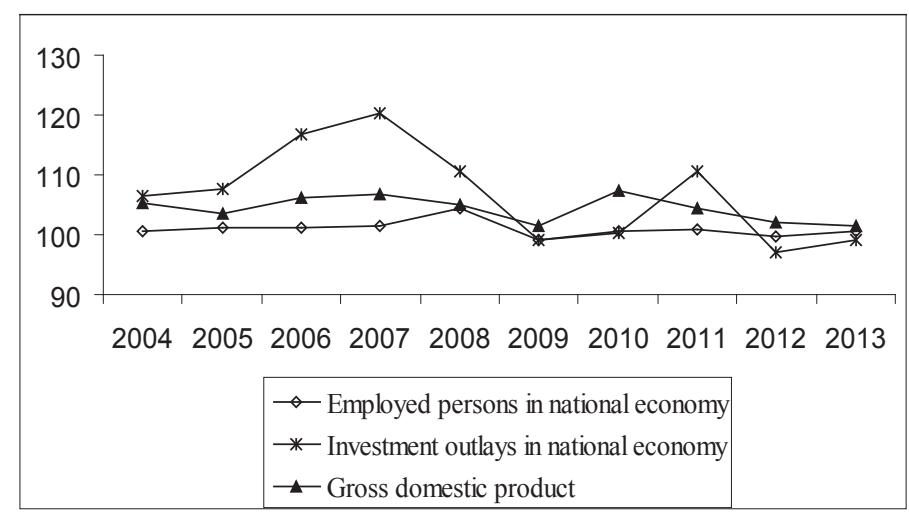

Source: Central Statistical Office of Poland, www.stat.gov.pl

The ownership transformation process was continuing in this period at a much slower rate. At of the end of 2012,86.4\% (80.7\% until 2003) of the total number of 
state-owned enterprises recorded in the REGON system (register on 30.06.1990) were already privatised (Fig. 2).

Figure 2: Share of the private sector in Poland's national economy (\%)

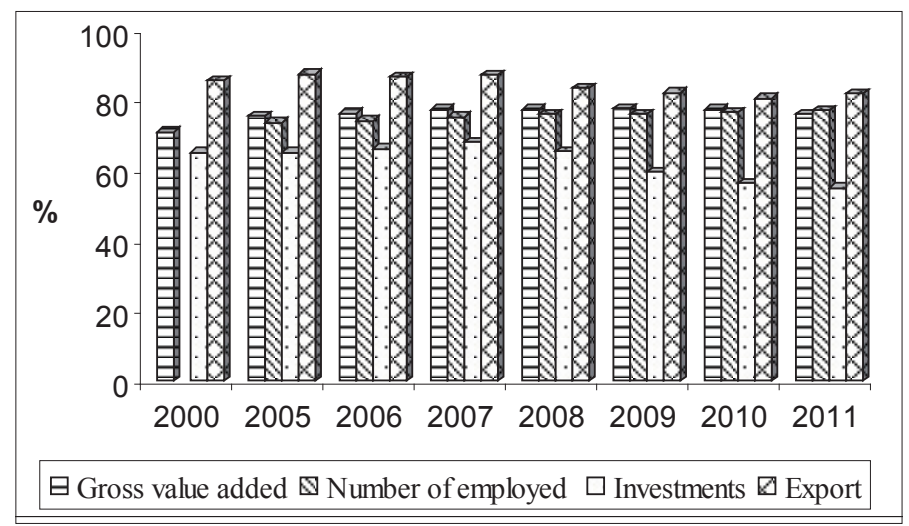

Source: Central Statistical Office of Poland, www.stat.gov.pl

Poland was a country, which avoided recession during the world financial crisis, with a slowdown in growth in 2009. "The Polish economy has proved to be more resilient to the crisis than not only the neighbouring countries of Central and Eastern Europe, but also than Southern and even Western Europe" (MAsik \& RZYsKi 2014, p. 132). Polish economic surveys found substantial differences between regions and subregions (NAZARCZUK 2008). The world economic crisis' impact decelerated not only the growth, results and efficiency of the economy, but also investment flows - both FDI and national - even after the crisis period (Fig. 1). Despite this, investments in the Polish economy in 2012 were 3.5 times higher than in 1990 (at constant prices).

The Ministry of Economics estimated results in the Polish economy during the period 2008-2012 as relatively good in comparison with other EU countries (Ministerstwo gospodarki 2014). A comparison of GDP growth in Poland and in the EU-27 in the period 2007-2012 shows significantly higher rates of growth in Poland, with the largest differences in 2009. The average growth for this period is respectively 4\% in Poland and only 0.4\% in EU-27 (Ministerstwo Rozwoju Regionalnego 2013). The comparison of real GDP growth for ten Central and Eastern European countries - members of the EU - and several Western European countries confirms a more favourable economic situation and development in Poland in the period 2003-2013 (Fig. 3). The Polish economy has developed more successfully in the conditions of EU market economy than the other post-Communist Central and Eastern European EU member states. 
Figure 3: Real GDP growth in selected EU countries (previous year=100)

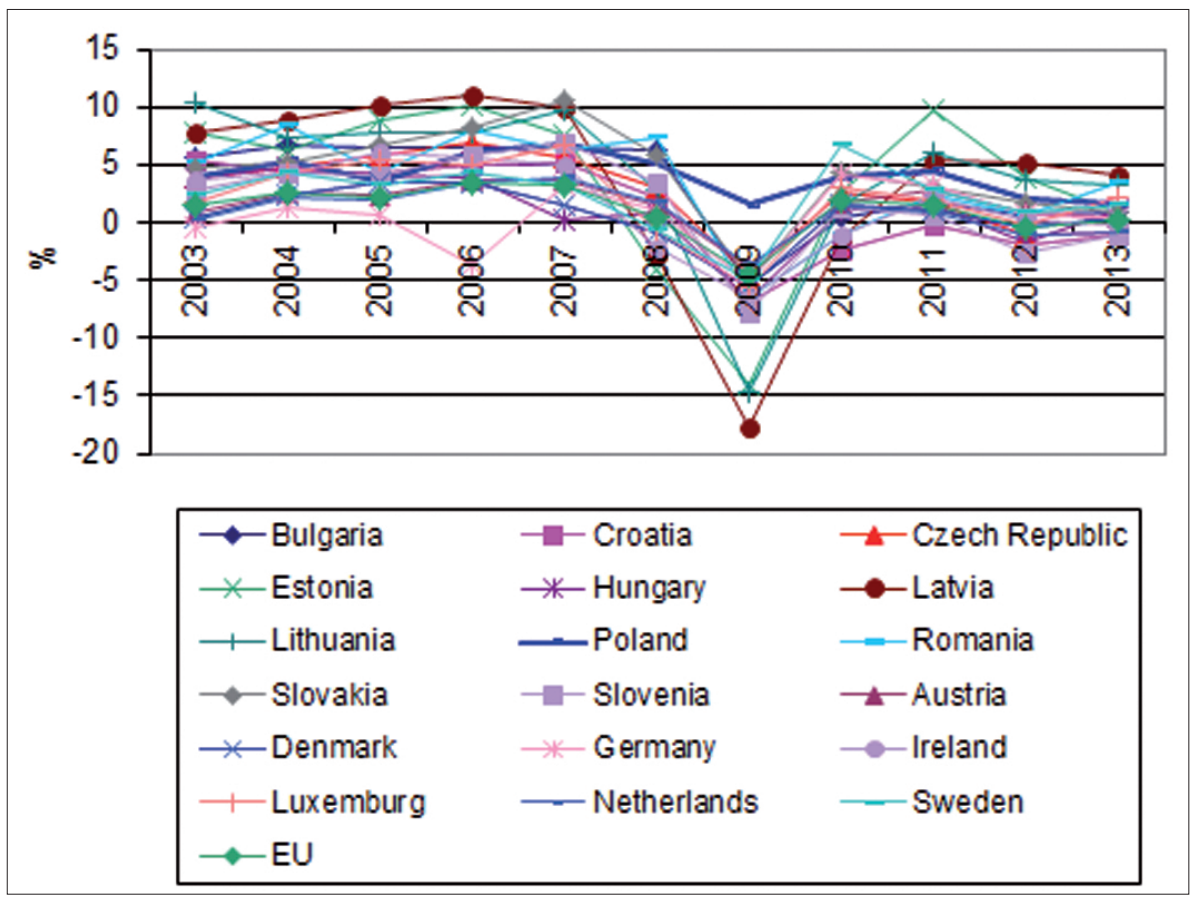

Source: EUROSTAT $<$ http://ec.europa.eu/eurostat>

"Since the beginning of the EU transition process, CEECs have continually received an increasing amount of foreign direct investment in the form of financial capital, fixed assets, knowledge (both codified and tacit) and technology. These have played an active and dynamic role in enhancing the industrial restructuring process and driving the (re)integration of CEECs into the world economy" (PUSTERLA \& RESMINI 2007, p. 636). It should also be noted as a positive fact that, according to UNCTAD, the transition countries have $6 \%$ of global FDI flows and the highest growth rate in the post-crisis period.

Sizeable FDI and EU financial support in Poland, both from pre-accession instruments (the biggest financial support from pre-accession programmes in comparison with other candidate or member countries) and European funds, are some important factors in promoting economic growth and regional development as well as the mitigation of social problems. "Poland's membership in the European Union has a stabilising effect on the conditions of functioning of the Polish economy and entering of our enterprises to the single European market and the inflow of Union funds will 
become a strong development impulse.” (Ministerstwo Regionalnego Rozwoju 2006, p. 17) Total EU funds, allocated for Poland for the years 2004-2006 (about 14 billion Euros) were utilised mainly for infrastructure development, support for enterprises and human resources development. "Since the beginning of the financial perspective 2007-2013, Poland became the largest recipient in the history of the European Union of the support from Cohesion Policy" - 68 billion Euros (www.mir.gov.pl). Poland will also be the largest recipient in the frame of Cohesion Policy in the programming period 2014-2020 (about 82.5 billion Euros). The implemented operational programmes in the frame of regional policy were changed in the last period in order to realise the objectives, included in national strategic documents. The main objectives for this period are: the creation of a competitive economy, modern infrastructure, and a better quality of life for Polish people.

Figure 4: GDP per capita in PPS in Poland and other EU countries (2013, EU 28=100)

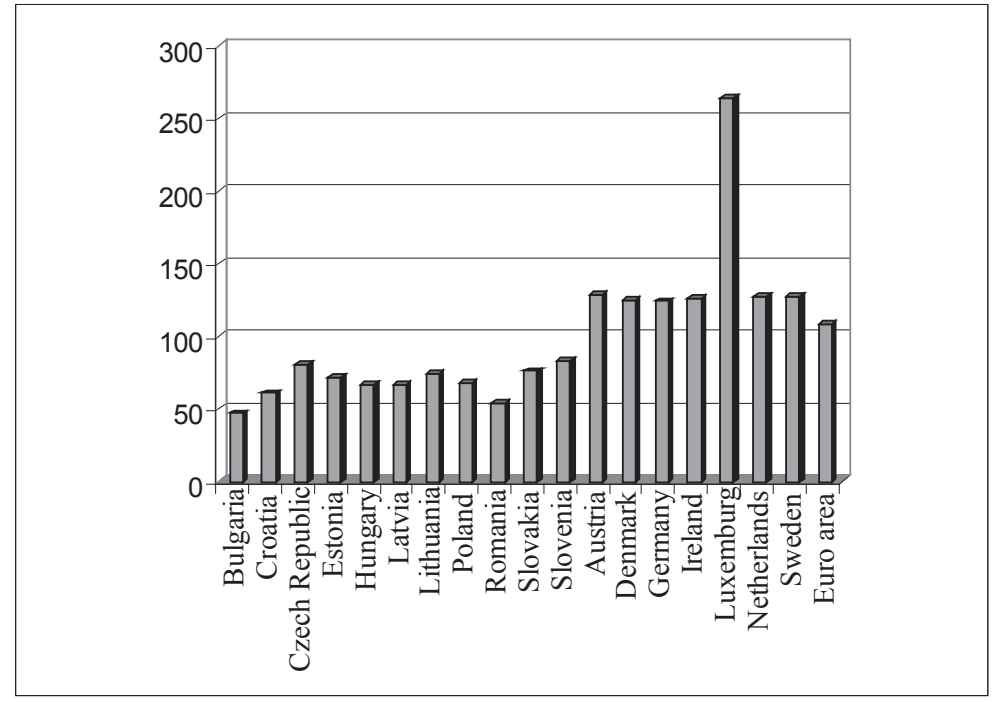

Source: EUROSTAT $<$ http://ec.europa.eu/eurostat $>$

As result of economic development, GDP per capita in Poland has increased in the last two decades and it is $67 \%$ of the average GDP per capita in Purchasing Power Standards (PPS) for the EU-28 in 2013 (Fig. 4). According to the Polish specialists' forecasts, if Poland and EU-28 in the following periods develop at the pace they were granted in 2000-2010, Poland will reach $75 \%$ of the average of EU-28 in the period 2011-2020 and 92\% in the 2020-2030 period (BIURo InwESTyCJI I CyKL EKonOMiczNyCH 2013). The income of the population is increasing, but earnings are still low compared 
to the rest of the EU. The population's preferences towards housing, both in urban and rural areas have changed in the last years. A greater increase in the number of family homes (by 15.2\%) than in the number of flats in blocks (by 4\%, 2002-2010) has been recorded. Many positive changes are observed in villages, located in suburban zones, especially of large cities.

Various demographic processes in Poland, as in many other European countries, have been deteriorating recently (reduced natural increase, population ageing, etc.). A high level of emigration, predominantly of the young population, is a very serious problem for the country. According to evaluations, about 2.1 million Polish people lived temporarily abroad in 2012. In addition, the Ministry of Infrastructure and Development indicates a deepening negative balance of internal migration from the peripheral areas in eastern, central and northern parts of the country. Regardless of this, the Polish population is characterised by more favourable demographic processes and structures in comparison with other European states. Nearby $50 \%$ of the residents of Poland are of 35 years old or less. "As a result Poland has the greatest number of young people in Europe entering the job market (almost half of the increase of the workforce in Europe in the resent years)." (Ministerstwo Rozwoju Regionalnego 2006, p. 12)

Positive changes are observed in the solving of some other social issues in the country. For example, the number of unemployed and the unemployment rate in the country has been decreasing in the recent period, but the unemployment rate remains higher than in other EU countries. According to surveys, youth unemployment and long-time unemployment is high, especially in rural areas and in areas away from the large cities, as is the case in other EU countries (Ministerstwo RozwoJU ReGionALNEGO 2013).

\section{Socio-economic changes by NUTS-2 regions}

A range of factors have affected regional development and growth, "such as physical and technological ones, social capital, cultural diversity, industrial and geographical characteristics" (MARROCU \& PACI 2013, p. 354) - natural conditions and resources, economic factors, investments, innovations, capital, human capital, knowledge, etc. Regions benefit "from higher human capital endowments and technological capacities, as well as from geographical factors such as proximity to markets or a location in the core. In the second of these explanations, new economic geography signals the presence of knowledge spillovers, common labour skills or forward/backward linkages as determinants of location patterns and, hence, specialisation." (Mora \& Moreno 2010, p. 312) Significant is the role of the cities in this development (FAFCHAMPS 2012). 
A diversified situation is observed in regional socio-economic development of Poland - higher economic growth in the most developed regions, the increasing rate of investment in weaker economic regions (Ministerstwo Rozwoju Regionalnego 2013). Data analysis of GDP, generated in the different voivodships (NUTS-2 regions), indicates a different degree of dispersion between them, depending on their relative share in the national GDP. The contribution of the best-developed region - the Masovian Voivodship [województwo mazowieckie], is more than $22 \%$ of the average national GDP, much higher than the second (best) region - the Silesian Voivodship [województwo śląskie] (about 13\%, 2012, estimate). Due to the more intensive socio-economic development of the Masovian Voivodship, its share is growing and the proportion between these regions is increasing - from 1.52:1 (2000) to 1.78:1 (2012, estimate). The four most-developed regions in Poland generate over 50\% of the national GDP and their share in the period after 2000 has increased (Table 1). ${ }^{1}$ At the same time the share of the four least-developed regions decreases. ${ }^{2}$ The WarmianMasurian Voivodship [województwo warmińsko-mazurskie] has a share very close to the regions in this group.

Table 1: Share of first- and last-ranking regions in Poland's Gross Domestic Product

\begin{tabular}{|c|l|r|l|r|}
\hline \multirow{2}{*}{ Year } & \multicolumn{2}{|c|}{ First four ranking in the regions } & \multicolumn{2}{|c|}{ Last four ranking in the regions } \\
\cline { 2 - 5 } & \multicolumn{1}{|c|}{ NUTS2 regions: } & $\%$ & \multicolumn{1}{|c|}{ NUTS2 regions: } & $\%$ \\
\hline 2000 & $\begin{array}{l}\text { w. mazowieckie, w. śląskie, w. } \\
\text { wielkopolskie, w. dolnośląskie }\end{array}$ & 50.9 & $\begin{array}{l}\text { w. świętokrzystkie, w. podlaskie, } \\
\text { w. lubuskie, w. opolskie }\end{array}$ & 9.7 \\
\hline 2005 & $\begin{array}{l}\text { w. mazowieckie, w. śląskie, w. } \\
\text { wielkopolskie, w. dolnośląskie }\end{array}$ & 51.9 & $\begin{array}{l}\text { w. świętokrzystkie, w. lubuskie, } \\
\text { w. podlaskie, w. opolskie }\end{array}$ & 9.5 \\
\hline 2010 & $\begin{array}{l}\text { w. mazowieckie, w. śląskie, w. } \\
\text { wielkopolskie, w. dolnośląskie }\end{array}$ & 53.1 & $\begin{array}{l}\text { w. świętokrzystkie, w. podlaskie, } \\
\text { w. lubuskie, w. opolskie }\end{array}$ & 9.1 \\
\hline $\begin{array}{l}\text { w. mazowieckie, w. śląskie, w. } \\
\text { wielkopolskie, w. dolnośląskie }\end{array}$ & 53.4 & $\begin{array}{l}\text { w. świętokrzystkie, w. podlaskie, } \\
\text { w. lubuskie, w. opolskie }\end{array}$ & 8.9 \\
\hline
\end{tabular}

Source: Authors' calculations based on the data from the Central Statistical Office of POLAND

Analysis of the proportion of the best (w. mazowieckie) and worst region (w. opolskie) in terms of GDP has also confirmed the increase in interregional inequalities

\footnotetext{
The table uses as criterion $25 \%$ of the analysed territorial units (16). The first and last ten regions cannot be taken into account because of the small total number of the regions in the country. The four best voivodships are used as a group with good results in Polish research.

2 The least-developed group used in much Polish research very often includes five voivodships - the Warmian-Masurian Voivodship is added to the above-mentioned in Table 2.
} 
between regions. This proportion rose steadily in the 2000-2012 period. The variation of GDP in PPS in regions at the NUTS-2 level in Poland increases due to a stronger economic growth in more highly developed regions, but remains below EU average (Ministerstwo Rozwoju Regionalnego 2013).

The trend towards growing regional differences in Poland is observed at the level of GDP per capita as well (Table 2 and Fig. 5). The difference between regions in different positions increases, despite the measures for regional cohesion implemented in the ongoing regional policy of the country. The gap between the Masovian Voivodship and other regions is due to the different regions' development, investment flows, EU funding, especially in the programming period 2007-2013, and many other reasons. There are very big differences between the individual regions of the country with respect to FDI flows. According to Polish surveys, the difference between the region with the largest FDI flows (Masovian Voivodship) and regions with the least ones is almost 50 times, while for FDI per capita it was only about 15 times (BIURO INWESTYCJI I CYKL EKONOMICZNYCH 2013). "Explicitly visible is the concentration of EU spending in the central-eastern zone as well as and in the western part of the country." (Ministerstwo Rozwoju Regionalnego 2013, p. 34)

Table 2: Dispersions between NUTS-2 regions in Poland by GDP per capita

\begin{tabular}{|l|r|r|r|r|}
\hline & 2000 & 2005 & 2010 & 2012 \\
\hline $\begin{array}{l}\text { Relation between region in the best position } \\
\text { to region in the worst position }\end{array}$ & 2.8 & 2.30 & 2.42 & 2.42 \\
\hline $\begin{array}{l}\text { Relation between region in the best position } \\
\text { to region in second (-best) position }\end{array}$ & 1.42 & 1.46 & 1.45 & 1.45 \\
\hline $\begin{array}{l}\text { Relation between region in the second (-best) } \\
\text { position to region in the worst position }\end{array}$ & 1.53 & 1.58 & 1.67 & 1.67 \\
\hline
\end{tabular}

Source: Authors' calculations based on data from the Central Statistical Office of Poland, www.stat.gov.pl

There is a good reason for the importance of the Masovian Voivodship and the capital city of Warsaw [Warszawa] in socio-economic development in Poland to continue during the next years: they are the territorial units with the highest concentration of economic activity and capacity for development in the country. The Masovian Voivodship reached a value over the EU-28 average GDP per capita in PPS in 2011.

Many Polish studies have found a deepening of regional disparities in the country (CZyż 1998; Szlachta 1995; WęCŁaWOWiCz 2005; Rydz 2006; TARKOWSKi 2008; etc.). This process is not unique to Poland. A similar trend is visible in other countries with 
Figure 5: Gross Domestic Product per capita by regions in Poland (2012)

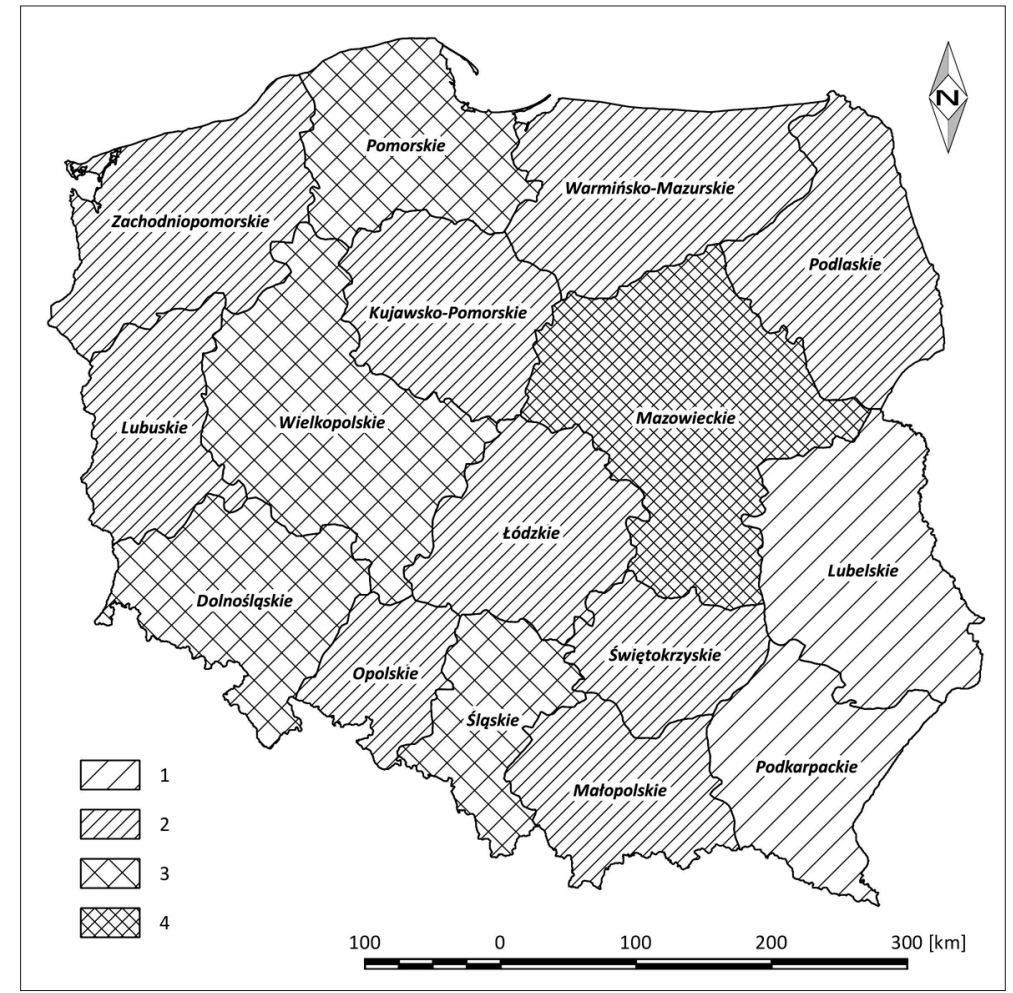

\section{GDP per capita (PLN):}

1 - less than 30,000 ;

2 - 30,001-40,000;

$3-40,001-50,000$;

4 - over 65,000 .

Source: Central Statistical Office, www.stat.gov.pl

transforming economies "despite governments' efforts to reduce them"3 - in Bulgaria, Hungary, Romania, etc. (Hrubi 2002; EnYedi 2005; Horvath 2009; Kallioras \& Petrakos 2010; Ilieva 2010, 2012, 2013a; IAnOȘ et al. 2013; etc.). The "development with increasing and decreasing territorial imbalances confirms the spatial theories according to which any development should be based on the existence of territorial gaps (HIRSCHMAN 1958). These gaps cause disruptions of symmetry to the regional development process, and the final result is a spiral evolution of the regions, similar to the cycle dynamics of a strongly anthropogenic territorial system (IANoş et al. 2011, 2013, p. 3).

"Regional growth and development are very closely related to the activities of innovative entrepreneurs." (BATABYAL \& Beladi 2013, p. 2) The analysis of the

3 In the words of Ianoș, Petrișor, Zamfir, Cercleux, Stoica \& TĂLÂngă (2013) 
territorial differences of the number of economic entities per 1,000 people (Fig. 6), of the investments in enterprises (Fig. 7), GDP per capita, and growth of GDP per capita by regions illustrates clearly a lower development of voivodships in Eastern Poland (w. warminsko-mazurskie, w. podlaskie, w. lubelskie, w. podkarpackie, w. şwiętokrzyskie). The voivodships in Eastern Poland, together with five regions in Bulgaria and five regions in Romania are the least developed parts of the EU. Researchers noted poor communication accessibility in the Podlachian Voivodship [województwo podlaskie], in the Precarpathian Voivodship [województwo podkarpackie] and in the WarmianMasurian Voivodship [województwo warmińsko-mazurskie] as one of the reasons for economic underdevelopment of these regions (Ministerstwo RozwoJU REGIONALNEGO 2013).

Figure 6: Number of economic entities per 1,000 people by regions in Poland (2012)

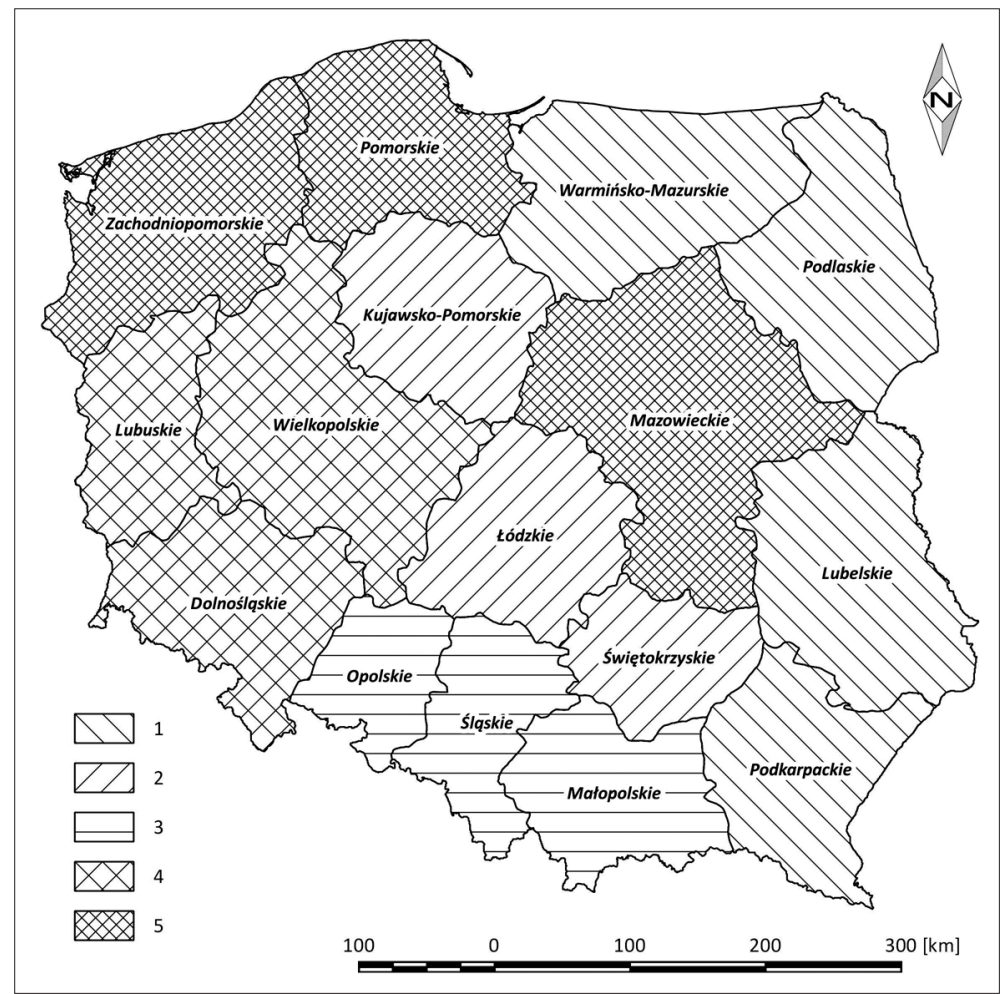

Number of economic entities per 1,000 people:

$1-72.7-84.8 ; \quad 2-84.8-97.7$;

3 -97.7-105.2; $\quad 4-105.2-115.7 ; \quad 5-115.7-131.9$.

Source: Pomorskie Biuro Planowania Regionalnego 2014 
Figure 7: Investments in enterprises per capita by regions in Poland (2012)

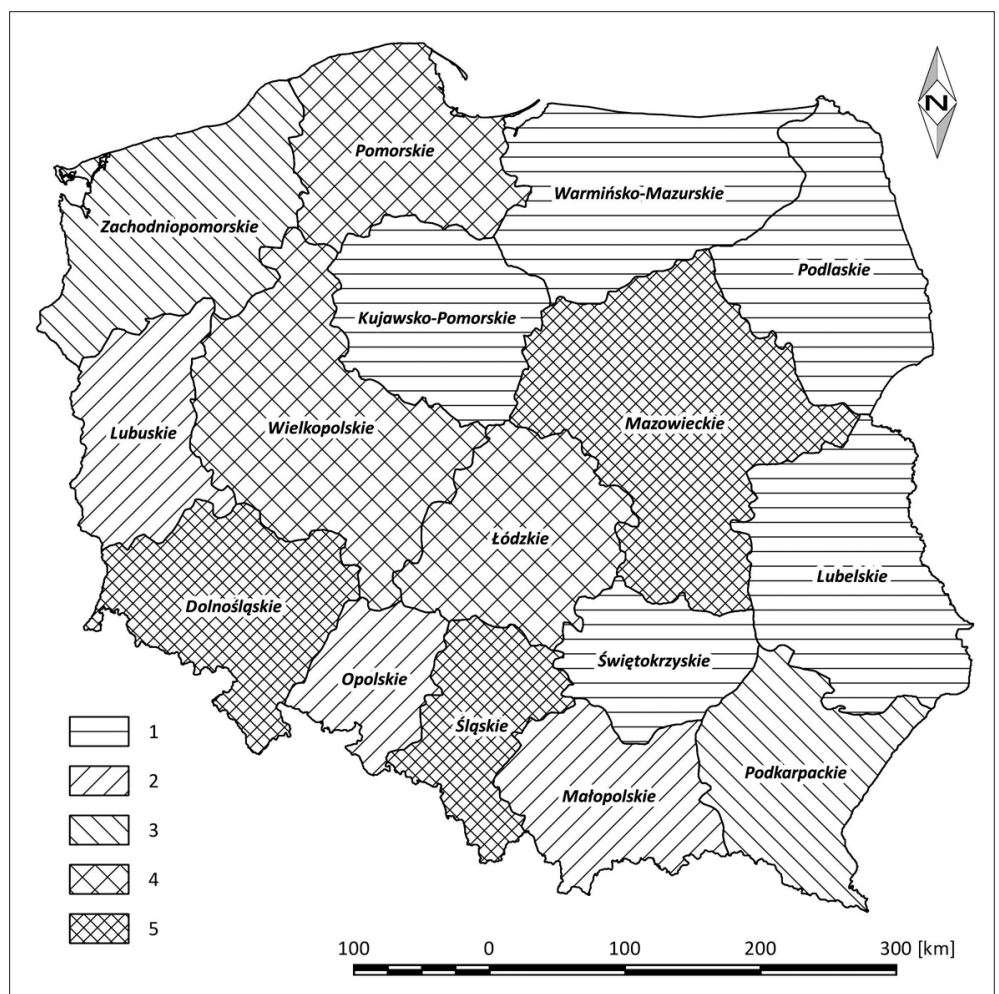

Investments in enterprises per capita (PLN):

$1-1,970-2,390 ; \quad 2-2,390-2,720$;

$3-2,720-2,920 ; \quad 4-2,920-3,330 ; \quad 5-3,330-5,260$.

Source: Pomorskie Biuro Planowania Regionalnego 2014

Eastern Poland has, since 2007, been an area of strategic intervention under all national operational programmes and saw the implementation of the special Operational Programme Eastern Poland. According to the National Spatial Development Concept 2030 "Eastern Poland needs measures supporting urbanisation processes, concentration of activity in voivodship cities, rural restructuring, and usage of political potentials due to its borderland location." (Ministerstwo Rozwoju Regionalnego 2012a) This impacts on the value of European co-financing in these regions (Fig. 8). 
Figure 8: EU co-financing per capita by regions in Poland (2012)

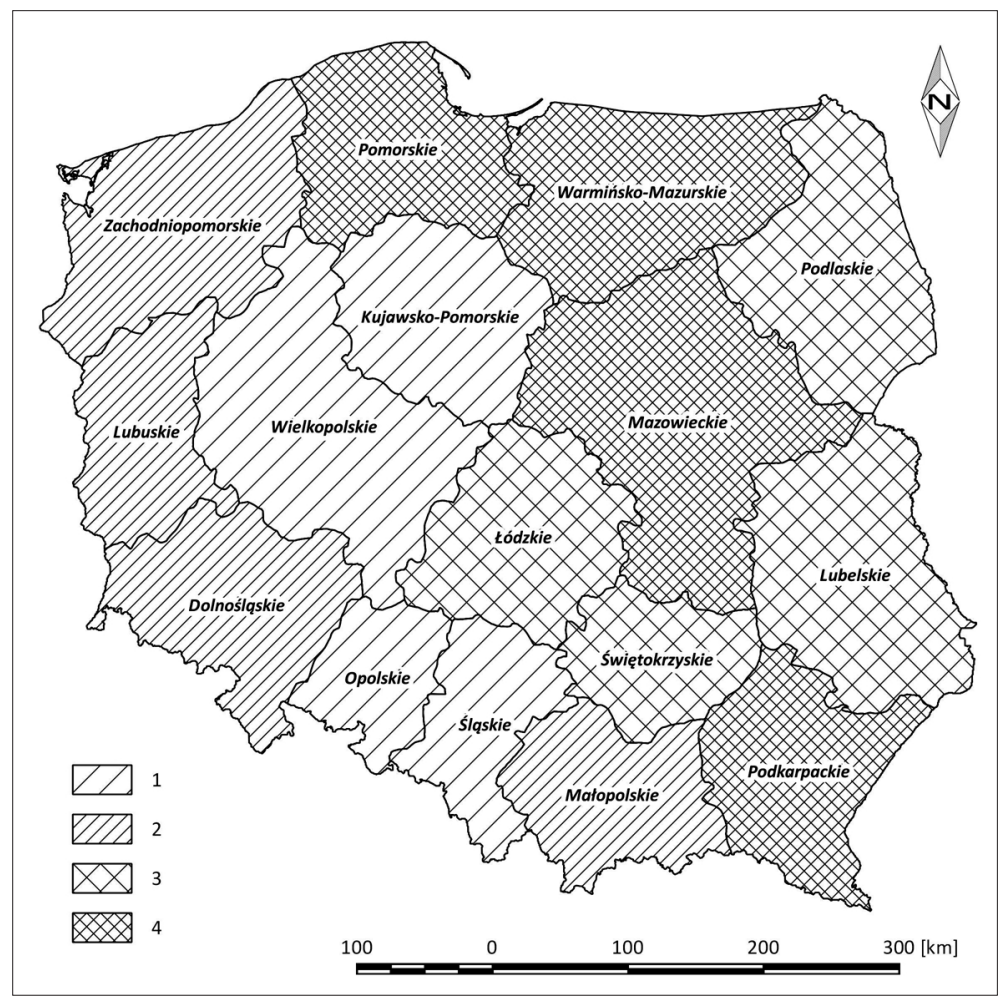

EU co-financing per capita:

$1-4,370-5,500 ; \quad 2-5,500-6,790$

$3-6,790-7,130 ; \quad 4-7,130-8,970$.

Source: Ministerstwo Rozwoju Regionalnego 2013

Large disparities in socio-economic development exist between sub-regions (NUTS-3) as well. Sub-regions with the best positions according to GDP per capita are those in some large cities (NUTS-3 of Warsaw - three times higher than the average for the country, NUTS-3 of Poznan - more than twice as high, 2010). The differentiation between NUTS-3 is the biggest in more developed voivodships. It is higher than the average in EU-27 and is increasing despite the regional policy applied. According to our calculations, the differentiation between sub-regions, measured by the dispersion of the GDP per capita indicator is 34.4 in Poland and 26.5 in EU-27 in 2009. The value of GDP per capita in the best-developed NUTS-3 in seven of the 16 voivodships of Poland is less than the average for the country. In this group there are sub-regions of all the five voivodships of Eastern Poland as well as in the Opole [województwo opolskie] 
and Lubusz [województwo lubuskie] voivodships (with the lowest indicators). There are big differences in EU-implemented financial support and the rate of its change. The analysis shows that EU funds to the regional voivodship capitals is about half that received in voivodship in most cases (Ministerstwo Rozwoju Regionalnego 2013).

\section{Socio-economic changes at the local level: Case study of Gołdap Municipality and the City of Bydgoszcz}

Examples of socio-economic changes at a local level in this paper are presented on the basis of two case studies - one relatively small urban-rural municipality from Eastern Poland and one of Polish cities, located in the north-western part of the country.

The Gołdap Municipality (22,000 inhabitants) is located in the north-eastern part of the Masurian area, in the Warmian-Masurian Voivodship, on the border with the Kaliningrad Region (Russia). This municipality, investigated during a 2012 field trip within the framework of a Bulgarian-Polish research project, is an example of successful local development. Large-scale changes occurred in this municipality in the 1990s and after Poland's accession to the EU - from a municipality with the highest level of unemployment in the country (about 50\%) after the liquidation of a large state agricultural farm (among the four largest state farms in Poland before 1989) to a municipality with prosperous economy and a low level of unemployment by the end of the investigation period. These positive changes are a consequence of the use of the advantages of its geopolitical location, of the resources for recreation, spa and tourism, of the implementation of significant financial support of European funds, and, of course, the significant efforts of local population and authorities. A checkpoint on the Polish-Kaliningrad border has been opened on the territory of the municipality (1995), a special economic zone (dominated by small and medium enterprises) has been shaped, a spa (the town of Gołdap received spa statute in 2000), tourism and winter sports have been developed, a number of new workplaces have been created, etc. Significant financial support has been obtained by both Gołdap Municipality and Gołdap County in the frame of the Operational Programme Eastern Poland and national operational programmes. Gołdap County holds the $18^{\text {th }}$ place among 312 powiats (counties) in Poland by received and implemented EU funds until 2012.

The City of Bydgoszcz (361,000 inhabitants) is one of the capitals of the KuyavianPomeranian Voivodship [województwo kujawsko-pomorskie]. ${ }^{4}$ It is the eighth-largest

4 The Kuyavian-Pomeranian Voivodship is one of two voivodships in Poland with two capitals with the residences of regional authorities. Its capitals are: City of Bydgoszcz and City of Torun. 
in terms of population among the cities in Poland - an economic, cultural, educational, touristic centre. This city was voted among the ten best tourist destinations in Poland in 2013 by tripadvisor.com.

The City of Bydgoszcz is the most developed part of the Bydgoszcz-Torun subregion (NUTS-3) and received the most EU financial support of the KuyavianPomeranian Voivodship in the programming period 2007-2013. Different projects are co-financed by EU funds in Bydgoszcz (Table 3). Regardless of its position, the value of implemented funds in this sub-region is much lower in comparison to sub-regions in best position in other voivodships (except the Opole Voivodship) and even less than in some sub-regions in worst positions (w. łódzkie, w. warmińsko-mazurskie). The difference between sub-regions in the best and worst position in the KuyavianPomeranian Voivodship is very small and this distinguishes it from other voivodships in the country.

Table 3: The largest projects with EU co-financing in the City of Bydgoszcz

\begin{tabular}{|l|r|r|}
\hline \multirow{2}{*}{\multicolumn{1}{|c|}{ Project }} & \multicolumn{2}{|c|}{ Investments } \\
\cline { 2 - 3 } & $\begin{array}{c}\text { Total } \\
\text { (million PLN) }\end{array}$ & $\begin{array}{c}\text { EU financial support } \\
\text { (million PLN) }\end{array}$ \\
\hline $\begin{array}{l}\text { BiT City (transport integration of cities } \\
\text { Bydgoszcz and Toruń) }\end{array}$ & 1,200 & 630 \\
\hline Trasa Uniwersytecka (wharf and bridge) & 211.6 & 92.7 \\
\hline Airport Bydgoszcz modernisation & 81.8 & 43.4 \\
\hline Regional Innovation Centre & 79.3 & 56.5 \\
\hline Wyspa Młyńska revitalisation (2005-2011) & 59.7 & EU -18.8 \\
\hline Main Library Kazimierz Wielki University & 45.5 & 31.9 \\
\hline $\begin{array}{l}\text { Educational Centre for Physical Culture and } \\
\text { Sports Kazimierz Wielki University }\end{array}$ & 42.7 & 29.3 \\
\hline Bydgoszcz Industrial and Technological Park & 43.5 & 14.1 \\
\hline Wyspa Młyńska's Marina & 16.5 & 5.9 \\
\hline Educational trail (Waterworks Museum) & 15.9 & 6.2 \\
\hline Academy of Music, Bydgoszcz & 11.4 & 6.1 \\
\hline Exploseum (historical museum) & 9.0 & 5.3 \\
\hline Kuyavian-Pomeranian Centre of Pulmonology & 6.7 & 4.35 \\
\hline
\end{tabular}

Source: www.bydgoszcz.gazeta.pl 
Analysis of contemporary socio-economic processes in the City of Bydgoszcz and its suburban zone shows significant changes in this area during the period of Poland's EU membership: an increase in its service functions as a centre of commerce, culture, sports, higher education, etc.; ongoing changes in the spatial structure of the city; continuation of suburbanisation processes, an increase in population and dwellings in suburban zone settlements, changes in functions and land use in these settlements; different types of change in the demographic structure and processes in the city and its suburban zone, etc.

\section{Conclusion}

This investigation shows some characteristic features of socio-economic changes in Poland in the period after its accession to the European Union at the national, regional and local levels. Analyses and comparisons are made with other EU countries suggesting more successful development of this country during the investigated period. The differences between NUTS-2 and NUTS-3 regions in Poland continue to grow slightly in the investigated period regardless of implemented regional and cohesion policy. The authors' observations show that similar examples of positive local changes can be detected in different parts of this country.

\section{References}

Batabyal A.A., Beladi H. (2013), Human capital, knowledge spillovers, and one kind of semiendogenous regional economic growth. In: Letters in Spatial and Resource Sciences, pp. 1-15. DOI 10.1007/s12076-013-0092-9.

Biuro Inwestycj I CyKL EkoNomiczNych (ed.) (2012), Szacunek PKB per capita i bezpośrednich inwestycji zagranicznich w województwach oraz wskaźniki wyprzedajace koniunktury. Ekspertyza <www.mir.gov.pl>

Bracalente B., Perugini C. (2010), The components of regional disparities in Europe. In: The Annals of Regional Sciences, 44, 3, pp. 621-645.

Conford J., Richardson R., Sokol M., Marques P., Gillespie A. (2006), Transformation of regional societies through ICTs: State(s) of the Art(s). A discussion document. Final version July 2006, Sixth Framework Programme.

CZYŻ T. (1998), Polaryzacja rozwoju regionalnego w okresie transformacji społecznogospodarczej w Polsce. In: PARysek J., Rogacki H. (eds.), Przemiany społecznogospodarcze Polski lat dziewięćdziesiątych. Poznań, Bogucki Wydawnictwo Naukowe.

DomaŃSKi R. (1997), Przestrzenna transformacja gospodarki. Warszawa, Wydawnictwo Naukowe PWN. 
Eberhardt P., Ilieva M. (2004), Results from economic transformation in Bulgaria and Poland in the end of XX century - beginning of XXI century. In: Problemi na geografiata, 1-2, pp. 22-32.

ENYEDI G. (2005), Processes of regional development in Post-socialist Hungary. In: BARTA G., Fekete E.G., Szorenyjne I.K., Timar J. (eds.), Hungarian spaces and places: patterns of transition, pp. 18-27. Pécs, Centre for Regional Studies of the Hungarian Academy of Sciences.

EUROPE 2020 STRATEGY <http://ec.europa.eu/eu2020.pdf>

Fabrizio S., Leigh D., Mody A. (2009), The second transition: Eastern Europe in perspective (= IMF Working Paper, 43). Washington, D.C., International Monetary Fund.

FAFCHAMPS M. (2012), Development, agglomeration, and the organization of work. In: Regional Science and Urban Economics, 42, 3, pp. 459-472.

Fassmann H. (1997), Regionale Transformationsforschung. Theoretische Begründung und empirische Beispiele (= Regionale Transformationsprozesse in Europa. Beitrage zur Regionalen Geographie, 44). Leipzig, Institut für Länderkunde.

FöRSTER H. (2000), Transformationsforschung: Stand und Perspektiven. In: Europa Regional, 3-4, pp. 54-59

GŁówny UrZąd Statystyczny (ed.) (1991-2012), Rocznik Statystyczny Rzeczpospolotej Polski. Warszawa.

GŁówny Urząd Statystyczny (ed.) (2014a), Polska w Unii Europejskiej 2004-2014. Poland in the European Union 2004-2014. Warszawa <www.stat.gov.pl>

GoRZElaK G. (1995), Transformacja systemowa a restrukturizacja regionalna. Warszawa, Europejski Instytut Rozwoju Regionalnego i Lokalnego.

Hirschman A. (1958), The strategy of economic development. New Haven, CT, Yale University Press.

Horvath Gy. (2009), Cohesion Deficiencies in Eastern and Central Europe - Inequalities of Regional Research Area (= Discussion Papers, 72). Pécs, Centre for Regional Studies of the Hungarian Academy of Sciences.

Horvath Gy. (ed.) (2002), Regional Challenges of the Transition in Bulgaria and Hungary (= Discussion Papers, Special Issue). Pécs, Centre for Regional Studies of the Hungarian Academy of Sciences.

Hrubi L. (2002), Old and new elements in the spatial structure of Hungary in the 1990s. In: Horvath Gy. (ed.), Regional Challenges of the Transition in Bulgaria and Hungary (= Discussion Papers, Special Issue), pp. 62-77. Pécs, Centre for Regional Studies of the Hungarian Academy of Sciences.

Ianoș I., Petrișor A.I., Zamfir D., Cercleux A.L., Stoica I.V., Tălângă C. (2013), In search of a relevant index measuring for territorial disparities in a transition country. Romania as case study. In: Die Erde, 144, 1, pp. 69-81.

ILIEVA M. (2002), Transformation in the territorial structure of Bulgarian economy in the 1990s. In: Horvath Gy. (ed.), Regional Challenges of the Transition in Bulgaria and Hungary (= Discussion Papers, Special Issue), pp. 49-61. Pécs, Centre for Regional Studies of the Hungarian Academy of Sciences.

ILIEVA M. (2010), Regional differences in the course of transformation processes in Bulgaria. In: KitowsKi J. (ed.), 20 years of social-economic transformations in countries of Central and Eastern Europe - an attempt of accounts (= Geopolitical Studies, 16). Warszawa, 
pp. 169-186. Warsaw, Polish Academy of Sciences, Institute of Geography and Spatial Organization.

ILIEVA M. (2012), Sotsialno-ikonomicheskata transformatsia v Bulgaria - osobenosti i teritorialni razlichia. Sofia, Izdatelstvo TerArt.

ILIEVA M. (2013a), Socio-economic transformation in Bulgaria. Saarbrücken, Lambert Academic Publishing.

ILIEVA M. (2013b), Regional differences and regional cohesion: case study of Bulgaria. In: Journal of Urban and Regional Analyses, V, 2, pp. 153-168.

Kallioras D., Petrakos G. (2010), Industrial growth, economic integration and structural change: evidence from the EU new member-states regions. In: The Annals of Regional Sciences, 45, pp. 667-680.

Kitowski J. (ed.) (2010), 20 years of socio-economic transformations in countries of Central and Eastern Europe - an attempt of accounts (= Geopolitical studies, 16), Warszawa, Warsaw, Polish Academy of Sciences, Institute of Geography and Spatial Organization.

Kollmorgen R. (2010), Transformation theory and socio-economic changes in Central and Eastern Europe. A conceptual framework (= emecon 1/2010) <www.emecon.eu/ Kollmorgen>

Ko£odko G. (2008), Wędrujący Świat. Warszawa, Wydawca Prószyński i S-ka SA.

Marrocu E., PACI R. (2013), Regional Development and Creativity. In: International Regional Science Review, 36, 3 (abstract).

Masik G., Rzyski S. (2014), Resilience of Pomorskie region to economic crisis. In: Bulletin of Geography, Socio-economic Series, 25, pp. 129-141 <http://dx.doi.org/10.2478/bog2014-0034>

Michalski T. (ed.) (2006), The geographical aspects of the transformation process in EastCentral Europe. Gdynia, Pelplin.

Ministerstwo Gospodarki (ed.) (2014), Polska 2014. Raport o stanie godpodarki. Warszawa $<$ www.mg.gov.pl>

Ministerstwo infrastruktury i RozwoJu (ed.) (2011), Sytuacja społeczno-gospodarcza Polski w 2010. Warszawa.

Ministerstwo Rozwoju Regionalnego (ed.) (2006), National Development Strategy 2007-2015. Warszawa $<$ www.mir.gov.pl $>$

MinisterstwoRozwojuRegionaLnEgo(ed.)(2012a),Koncepcjaprzestrzennegozagospodarowanis kraju 2030. Warszawa <www.mir.gov.pl $>$

Ministerstwo Rozwoju Regionalnego (ed.) (2012b), Strategia rozwoju kraju 2020. Warszawa $<$ www.mir.gov.pl>

Ministerstwo Rozwoju Regionalnego (ed.) (2013), Przeglad Regionalny Polski 2012. Warszawa $<$ www.mir.gov.pl>

Mora T., Moreno R. (2010), Specialization changes in European regions: the role played by externalities across regions. In: Journal of Geographical Systems, 12, 3, pp. 311-334.

Mync A., Komornicki T. (2000), Regionalne zróżnicowanie procesów rozwoju społecznogospodarczego kraju w okresie transformacji. In: Ekonomista, 5, pp. 669-688.

NAZARCZUK J. (2008), Wpływ światowego kryzysu finansowego na gospodarkę Polski i jej regionów. In: KisIEL R., WoJarska M. (eds.), Wybrane aspekty rozwoju regionalnego. Olsztyn, Fundacja „Wspieranie i Promocja Przedsiębiorczości Warmii i Mazurów” $<$ www.akademia.edu $>$ 
PARYSEK J. (1998), Efekty procesu transformacji społeczno-gospodarczej w Polsce. Bilans okresu 1989-1996. In: Parysek J., Rogacki H. (eds.), Przemiany społeczno-gospodarcze Polski lat dziewięćdziesiątych. Poznań, Bogucki Wydawnictwo Naukowe.

Petrakos G. (2002), The Balkans in the new European economic space. In: Eastern European Economics, 40, 4, pp. 6-30.

Pomorskie Biuro Planowania Regionalnego (ed.) (2014), Główne przekszałcenia społeczne i gospodarcze województwa pomorskiego <www. pbpr.pomorskie.eu $>$

Pusterla F., Resmini L. (2007), Where do foreign firms locate in transition countries? An empirical investigation. In: The Annals of Regional Sciences, 41, pp. 835-856.

RYDZ E. (2006), Przemiany struktur społeczno-gospodarczych w okresie transformacji systemowej na Pomorzu Środkowym. Słupsk, Wyd. Pomorskiej Akademii w Słupsku.

Smith A., Pickles J. (eds.) (1998), Theorising transition: the political economy of post-communist transformation. London, Routledge.

Stadelbauer J. (2000), Räumliche Transformationprozesse und Aufgaben geographischer Transformationsforschung. In: Europa Regional, 3-4, pp. 60-71.

SZANYI M. (2013), Large-scale transformation of socio-economic institutions - comparative case studies on CEECs. Background Paper 3: Varieties of capitalism and CEECs, July. Seventh Framework Programme, Socio-economic sciences and humanities Europe moving towards a new path of economic growth and social development $<$ www.foreurope.eu $>$

Szlachta J. (1995), Regional development in Poland under transformation. Warsaw, Friedrich Ebert Stiftung.

TARKowski M. (2008), Centra i peryferie rozwoju społeczno-gospodarczego Polski w okresie transformacji ustrojowej. Gdynia, Pelplin.

WĘCEAWowicz G. (2005), Where the grass is greener in Poland: regional and intra-urban inequalities. In: Lee R., Smith D.M. (eds.), Geographies and Moralities. International Perspectives on Development, Justice and Place, pp. 62-77, Oxford, Blackwell Publishing.

http://ec.europa.eu/eu2020.pdf

www.bydgoszcz.pl

www.bydgoszcz.gazeta.pl

www.goldap.pl

www.mir.gov.pl 